\title{
GLAUBER SOB UM REGIME DE URGÊNCIA
}

\author{
Érico Araújo Lima*
}

Resumo: Neste artigo, tento colocar em relevo dois filmes de Glauber Rocha, $D i$ Cavalcanti (1977) e Claro (1975), a partir de um enfoque no que poderia ser considerada uma modulação no pensamento do realizador, rumo a uma anti-razão. Apostando em novos caminhos para uma arte política, haveria nessas pesquisas - e também no texto sobre a estética do sonho - uma inflexão para a irrupção de novas formas de experiência, no que seria possível propor como um regime de urgência da imagem, em que a linguagem é liberada para outras modalidades de contágio com o real.

Palavras-chave: Glauber Rocha, urgência, sonho, delírio.

Resumen: En este artículo tratamos de poner de relieve dos películas de Glauber Rocha, Di Cavalcanti (1977) y Claro (1975), a partir de un enfoque en lo que podría considerarse una modulación en el pensamiento del director, rumbo hacia un anti-razón. Apostando por nuevos caminos hacia un arte político, habría en esas investigaciones $-\mathrm{y}$ también en el texto sobre la estética del sueño- una inflexión hacia la irrupción de nuevas formas de experiencia, en lo que sería posible proponer como un régimen de urgencia de la imagen, donde el lenguaje se libera hacia otras modalidades de contagio con lo real.

Palabras clave: Glauber Rocha, urgencia, sueño, delirio.

Abstract: In this article I try to put in evidence two films of Glauber Rocha, $D i$ Cavalcanti (1977) and Claro (1975), from an emphasis on what could be considered a modulation in the mind of the director, towards an anti- reason. Betting on new researches for a political art, we could find in those films - and in the text on the aesthetics of dream a shift to the emergence of new forms of experience. It would be possible to propose this problem as a regime of urgency of the image, where the language is released to other forms of relation with the real.

Keywords: Glauber Rocha, urgency, dream, delirium.

Résumé: Dans cet article, nous essayons de mettre en évidence deux films de Glauber Rocha, Di Cavalcanti (1977) et Claro (1975), à partir d'une focalisation sur ce qui pourrait être considéré comme une modulation dans l'esprit du réalisateur, vers une antiraison. Dans une recherche sur de nouvelles propositions pour un art politique, il s'agit dans ces films - et dans le texte sur l'esthétique du rêve - d'un changement de pensée, où l'émergence de nouvelles formes d'expérience se pose comme question fondamentale. Il serait possible de proposer les procédures filmiques comme un régime d'urgence de l'image, où le langage est libéré pour rencontrer d'autres formes de rapport avec le réel.

Mots-clés: Glauber Rocha, urgence, rêve, délire.

* Doutorando. Universidade Federal Fluminense, Programa de Pós-graduação em Comunicação, LEE-Laboratório de Estudos e Experimentações em Audiovisual da Universidade Federal do Ceará. 60455-769, Fortaleza, Brasil. E-mail: ericooal@gmail.com

Submissão do artigo: 31 de maio de 2015. Notificação de aceitação: 20 de agosto de 2015. 


\section{Gestos de impulso}

"Di Cavalcanti foi feito num impulso. Acordei de manhã, sete e meia, li que o Di Cavalcanti tinha morrido, nove horas fui filmar" (Rocha, 2006: 332), retoma Glauber Rocha a respeito do curta que realizou em 1977 logo que soube da morte do amigo e pintor Di Cavalcanti. Há aí um gesto de arrancar imagens e sons do mundo, produzir cinema num movimento tomado por forças imprevistas e por uma abertura ao descontrole. Falar em um regime de urgência nessas imagens implica, desde já, um mergulho em experiência de tensão com modalidades de planejamento e regra. A imagem é ela mesma um processo de experimentação. É no limite que Glauber filma e monta o curta. No limiar das possibilidades de efetivar uma filmagem de um velório e de um sepultamento, vai com a câmera em close-up no rosto do pintor que morreu. " $1,2,3,4,5,6,7,8,9,10,11,12$. Corta! Agora dá um close na cara dele!", diz o realizador, na faixa sonora incluída após as filmagens, quase numa descrição do processo. Estamos no entremeio de uma experiência estética porosa, aberta às trocas, intempestiva. O que se dá nesse meio, nessa zona de indiscernibilidade que passa a ser delineada? É de qual ordem esse encontro tão urgente? Glauber desencadeia um processo que faz a mistura entre olhares, sensibilidades e temporalidades. "Ninguém assistirá ao enterro da tua última quimera. Somente a Ingratidão - esta pantera - foi a tua companheira inseparável": os versos de Augusto dos Anjos são entoados por Glauber e seriam ainda um título para o filme.

Todo o caos promovido em Di Cavalcanti tem a ver com pesquisas estéticas em que o aleatório, o simultâneo e o descontrole seriam condutores da fabricação fílmica. Nessa experiência, a questão é deixar-se tomar por forças capazes de arrastar para algo novo. Trata-se de fazer o movimento e desencadear transformações. Nos encontros promovidos pela imagem, é possível gerar torções e resistir aos enquadramentos dos corpos, que podem se libertar em percursos de relação com o outro. A experiência estética nessa 
região perde uma direção clara e faz fissura com uma organicidade e com uma linha dominante e ordenadora da percepção. No turbilhão, o que se tem é alteração de si, dos sentidos, uma incapacidade de síntese, de organização de significados. Uma polifonia barroca prolonga as intensidades e multiplica as vozes, que aqui já não remetem a uma verticalidade capaz de reunir o conjunto, mas estão a todo o momento em choques e rodopios, em trajetos disjuntivos.

Filmar como quem não sabe filmar. Filmar sem o cálculo ordenador da experiência, abrir-se às bifurcações de possíveis que o próprio processo pode desencadear. A imagem não tem clareza, os corpos não estão com lugar marcado e direcionamento claro. Com $D i$, o realizador acrescenta possibilidades para a produção de olhares. Prolifera mesmo os possíveis para fazer cinema, numa estética com gritos, misturas, impurezas, desordenamento. É toda uma ocupação de espaço marcada pela errância: era assim já nas filmagens de Câncer (Glauber Rocha, 1968-1972), em 1968, quando ia para as ruas do Rio de Janeiro sem planejamento do que fazer, sem roteiro, apenas com a proposta de deixar ações acontecerem em frente a uma câmera ligada, em planos-sequência; era assim na experiência do exílio, com Claro (Glauber Rocha, 1975), perambulador das ruas de Roma, dando orientações sobre os enquadramentos no ato de filmagem, com posteriores sobreimpressões de camadas, fusões na imagem, simultaneidades de blocos sensíveis reunidos na montagem.

Essas experiências de urgência são operações de risco, poderia ser dito. Um cinema que se dá na tensão com o mundo, que parte para o encontro numa tentativa de escapar ao controle dos programas, no que trago as discussões desenvolvidas por Comolli (2008). Se a roteirização da vida se espalha, é preciso buscar outros métodos para fazer com que os filmes aconteçam. A proposição de Comolli marca uma defesa de uma postura do documentário frente ao caráter consensual dos roteiros. A experimentação do risco faz surgir cenas, que se constituem de forma aberta e em meio a um 
imponderável. Fugir ao controle de uma previsibilidade, sair de zonas de segurança, desarranjar, borrar. "Os filmes documentários não são apenas 'abertos para o mundo': eles são atravessados, furados, transportados pelo mundo" (Comolli, 2008: 170). Deixar-se furar pelo mundo seria uma postura política que se constitui como um modo de agir na polis, em gesto indisciplinado. Furar: há na proposta de Comolli uma radicalidade que diz respeito mesmo a uma maneira de se dispor ao encontro. Pois não basta a postura da abertura. É preciso uma atitude mais drástica que se opera na escritura mesma do filme, um movimento de deixar que o mundo faça a fissura no filme, crie buracos e fendas. Quando furo, exponho algo ao indecidível, invento caminhos e permito que sejam traçadas bifurcações. A figura conceitual da fissura tem grande importância aqui, como modo de resistência potente para pensar a experiência estética do cinema. "Longe da 'ficção totalizante do todo', o cinema documentário tem, portanto, a chance de se ocupar apenas das fissuras do real, daquilo que resiste, daquilo que resta, a escória, o resíduo, o excluído, a parte maldita" (Comolli, 2008: 172). $\mathrm{O}$ que resiste faz fugir, inventa outras perspectivas para apreender o mundo, para recortar o espaço e o tempo, para constituir mise-en-scènes. A parte maldita é tensionadora de formas majoritárias de organizar a experiência. Ela é o que foi colocado fora de uma partilha do sensível e vem introduzir, então, uma cena litigiosa, expondo um erro de contagem (Rancière, 1996). Ela é o que resiste apesar de tudo (Didi-Huberman, 2012a). Mas como lidar com essa parte maldita? Quais procedimentos estão envolvidos na tensão gerada pelo pequeno, pelo resíduo? Seria uma simples questão de incluir aquele que está fora?

Glauber sofre um grande impacto ao saber da morte do amigo Di Cavalcanti. Ele filma porque é fundamental fazer essa homenagem nesse momento, estar ali no velório com a câmera. Nesse processo singular, em que um filme se faz desencadeado pelo aqui e agora de uma notícia trágica, a tensão com uma forma prévia de imagem é instituinte do movimento, e o 
filme se faz como um resíduo que não procura legitimidade, porque guarda na potência mesma de um pequeno gesto a dimensão política capaz de instaurar um desacordo sensível no mundo. É uma tensão com a relação canônica que se prescreve para as sensibilidades diante da morte e é uma perturbação fundamental no próprio cinema. Em uma das sequências que penetra o fluxo das imagens do filme, Glauber e os amigos da equipe estão com vários livros e revistas que têm reproduções das pinturas do pintor homenageado. Eles parecem, muitas vezes, fazer quase um vídeo caseiro, reunidos ali para erguer publicações, folhear páginas, abrir um livro para mostrar um pouco mais de uma imagem que está em alguma parte dali. Não existe uma composição de quadro rigorosa, a câmera faz parte daquela reunião de pessoas numa casa, seres que estão juntos, sobretudo, pelo desejo de fazer um filme que possa festejar a vida de Di Cavalcanti. De repente, surge um espelho, em torno do qual todos parecem fazer pequenas brincadeiras, experimentar o que resulta de um encontro com essa superfície. E tudo isso se passa em meio à fala desordenada de Glauber, que conta os próprios encontros com $\mathrm{Di}$ ou que passa a descrever o que se passou no velório, sempre numa corrente de devires completamente embaralhados e livres de uma dominante de organização. Uma marchinha de carnaval de Lamartine Babo cria o tom de samba para essas imagens. A operação delas é diferente daquelas que surgem logo no início do filme, a câmera dentro de um carro que percorre as ruas rumo ao Museu de Arte Moderna, local do velório, ou quando se está filmando o próprio corpo morto no centro do salão. Mas é justo um procedimento de leveza que vem se articular ao espaço mais solene, um tom que vai contaminando o filme todo, porque o que também é urgente é a celebração, mais do que o lamento.

Seria possível dizer que estamos, nessa experiência, diante de imagens urgentes, imagens que queimam (Didi-Huberman, 2004, 2008, 2012b). Dentre outras maneiras, elas queimam "com seu movimento intempestivo, incapaz de parar no caminho (como se diz 'queimar as 
etapas'), capaz de sempre bifurcar-se, de ir bruscamente a outra parte (como quando se diz 'arder de inquietude')" (Didi-Huberman, 2008: 52). Ao tocarem o real, as imagens incendeiam, desencadeiam modos inquietantes para o ver, lançam outras perspectivas de temporalidades, maneiras outras de ter com o mundo. Elas não se adequam a uma lógica formatada do sensível, tomam espaço com um movimento que não pode ser parado, na constante sístole e diástole e no jogo de tensores de uma experiência cindida. Elas não são uma organização clara e bem ordenada do sensível, mas um rodopio, uma maneira de se espalhar e de confrontar o turbilhão. O cinema que queima pode teimar em ser enquadrado num modelo e também evitar ser ele mesmo um indicador autoritário de posturas de corpos dos seres filmados, sejam os corpos de homens ordinários, sejam mesmo as paisagens como corpos - a cidade, talvez, como um ser, em processos de individuação. Diante do mundo em movimento, a cena desencadeada pelo cinema se situa em região produtora, zona de constantes variações e heterogeneidades. Diante do corpo de Di Cavalcanti e da vida a ser festejada, cabe produzir uma imagem que é pura inquietude e agitação, queimando sucessões, ultrapassando limites, fazendo saltos. Retomando as discussões de Comolli, vale lembrar que "o movimento do mundo não se interrompe para que o documentarista possa lapidar seu sistema de escrita" (Comolli, 2008: 177). A tentativa de pôr em ordem vai, então, estar em perpétua tensão com as variabilidades sensíveis em jogo na própria vida, intermitente e instável. A decisão de dar o close no rosto do morto é intempestiva, no ato, em meio a todo um mundo que não para de se revolver e mesmo em meio ao incômodo da família que chega a demonstrar a inquietude com as filmagens, como chega a indicar Glauber na voz off.

Filmar sob o risco seria partir para um processo de imponderabilidades, para caminhos tortuosos. Daí a impossibilidade do roteiro, como defende Comolli, e a necessidade mesma do documentário. "Filmar os homens reais no mundo real significa estar às voltas com a 
desordem das vidas, com o indecidível dos acontecimentos do mundo, com aquilo que do real se obstina em enganar as previsões" (Comolli, 2008: 176). Existem lacunas, intervalos. Uma postura política é situar-se na indiscernibilidade que esse espaço intervalar abre, como potência para a invenção de cenas e de novas possibilidades para ocupar o mundo. "Sentir aquilo que, no mundo, ainda nos ultrapassa. As narrativas ainda não escritas, as ficções ainda não esgotadas" (Comolli, 2008: 177). Apesar de tudo, há algo ainda. Caminhos a serem explorados, posturas de corpos a serem inventadas, experiências a serem fruídas. Nas brechas que se abrem, podem estar contidas as potências para as roturas; na dimensão do inacabado, o desejo de sentir outras relações entre próximo e distante, entre luzes e sombras, entre vida e morte; num impulso com pontas de negativo, o desejo de filmar apesar de tudo, de partir para o encontro e fazer com que as imagens e os sons aconteçam. O filme e as filmagens, na resistência ao controle, tornam-se acontecimentos. A precariedade da escritura que desponta em Di Cavalcanti é uma condição de invenção de novos espaçostempos.

Eis porque os dispositivos do documentário são antes de tudo precários, instáveis, frágeis. Eles são úteis apenas para permitir a exploração do que ainda não é de todo conhecido. Os roteiros de ficção são, frequentemente (cada vez mais), fóbicos: eles temem aquilo que lhes provoca fissuras, que os corta, os subverte. Eles afastam o acidental, o aleatório. Alimentados pelo controle, eles se fecham sobre si mesmos. Retroação. O não-controle do documentário surge como condição de invenção. Dela irradia a potência real deste mundo. (Comolli, 2008: 177).

O que é preciso fazer para que haja um filme? Existem condições de possibilidade? O impulso da realização em Di Cavalcanti traz que implicações para as maneiras de fazer e pensar cinema? O gesto fílmico do curta de Glauber implica, num primeiro momento, desejo. É a partir daí que são reunidos amigos, para celebrar a vida do pintor Di Cavalcanti, também 
ele amigo do realizador. É como produção desejante que a equipe parte para as ruas e arrisca fazer imagens no velório e no enterro do artista. Risco no contato com o mundo, risco na criação de uma relação. Já um outro sentido para a ardência da imagem: "A imagem queima com o desejo que a anima, com a intencionalidade que a estrutura, com a enunciação, inclusive com a urgência que manifesta (como quando se diz 'ardo de desejo' ou 'ardo de impaciência')". (Didi-Huberman, 2008: 51). O trabalho de homenagem ganha contornos de uma experiência que perturba a ordem da cerimônia configurada para o ato de despedir-se dos mortos. A chave do transe, tão cara ao pensamento cinematográfico de Glauber, vai aqui operar mesmo uma ideia de transformação e de delírio, na elaboração de um ritual descentrado, marcado por desequilíbrios e pelo caos. E o transe vai ter conexão com a ideia mesma de trânsito, de operar passagens, de arrastar o corpo, a vida, as imagens e os sons num movimento. $\mathrm{O}$ corpo velado e sepultado de Di Cavalcanti é profanado porque precisa ser misturado, para que já não estejamos na dimensão sagrada, do que foi separado (Agamben, 2007). No contágio com o mundo, é fabricado o filme, que é tomado pelo efeito transformador do outro, que se aventura no lugar do intervalo, do meio, região repleta de perigos. A obra funda para si as próprias condições de possibilidade, a partir da postura de enfrentamento com o que se apresenta como dado e como separado. Traz para si a experiência do limiar, de uma polifônica associação de imagens e sons, formas em desarranjo, em quebras, em livre corrida pelo mundo.

Também sem passar por longo período de preparação, Claro é rodado durante 15 dias em Roma, numa abordagem ensaística que mistura blocos de deriva nas ruas e cenas de interior em que se esboçam situações ficcionais. Como destaca Mateus Araújo Silva (2012), todo o filme fica pronto em cerca de dois meses e meio, após um processo sem roteiro prévio, com amigos, câmera na mão e som direto. Aqui há um mergulho delirante em relação com a própria cidade, com questões tão caras a Glauber, em 
crítica ao capitalismo. As imagens têm nelas mesmas uma processualidade, uma escritura marcada por planos que não estão previamente estabelecidos, por tensões com os que passam e estranham Juliet Berto em movimentos errantes pelas ruas, por uma câmera que vai expondo a própria busca nos caminhos que experimenta. "A incursão de Glauber e Juliet é uma aventura em terreno desconhecido, atravessada pela instabilidade de um gesto desmedido e insólito" (Silva, 2012: 262). Trata-se, muitas vezes, de um filme de viagem, uma obra atenta às implicações do fazer filme para a vida, uma experiência que pode ter muito a ver com incursões de Glauber pelo Super8, como no trabalho que chamou de Letícia e Mossa no Marrocos (1971), ${ }^{1}$ feito com as amigas Letícia Maria Moreira de Souza e Flora Bildner (Mossa), em viagem a Marrakech, depois de rodar Cabeças Cortadas, na Espanha. Glauber no exílio em busca da vida.

Esses gestos de Di Cavalcanti e de Claro guardam uma estreita proximidade ainda com outro filme de Glauber, Câncer, realizado em 1968 e montado em 1972. Era também de uma urgência e de uma vibração desejante que se tratava essa outra obra. Arriscaria aqui dizer que há mesmo um prolongamento das tensões desencadeadas pelos filmes, cada um com uma pesquisa própria, mas todos profundamente marcados por um mergulho intempestivo no mundo, sem estabelecimentos prévios de direções, sem hierarquias na organização da experiência, sem uma territorialidade ordenadora de caminhos. ${ }^{2}$ No caso do trabalho de 1968, Glauber estava prestes a filmar O Dragão da Maldade contra o Santo Guerreiro (1969), mas por problemas burocráticos, as latas de negativo foram presas na alfândega, e a espera deixava o realizador ansioso. Ele queria fazer um

\footnotetext{
${ }^{1}$ Trata-se de um filme ao qual, infelizmente, não tive acesso e que cito aqui brevemente, apenas a partir do que pude ler a respeito dele, nas compilações das filmografias do realizador, como a que está disponível no site do Tempo Glauber: www.tempoglauber.com.br. Sabe-se que Glauber teve algumas experiências em Super8 no exílio, inclusive com a própria Juliet Berto, o que pode indicar novas modalidades de pesquisa, uma experimentação de mais caminhos.
} 
filme, partir para as ruas, experimentar possibilidades. Chamou amigos que já estariam no Dragão e realizou filmagens em quatro dias, sem roteiro, sem dizer previamente aos atores uma história, apenas dando situações de violência que deveriam ser improvisadas diante da câmera em planosequência, até terminar o tempo de cada chassis de uma Éclair $16 \mathrm{~mm}$. Os rolos de negativo preto-e-branco utilizados eram antigos, já em fase de deterioração, que estavam na Mapa Filmes, produtora do amigo de Glauber, Zelito Viana. Eram negativos não utilizados, restos, sobras. E o filme se deu em meio ao aleatório e ao acaso, em desnorteio e desordem dos sentidos. Deixado de lado por quatro anos, porque Glauber não via grande importância no que havia feito (Rocha, 2004: 180), só é montado em 1972, quando os trânsitos e as dobragens da vida e do tempo já tinham remodelado a experiência do diretor e mesmo as imagens e os sons produzidos. A obra cruza temporalidades e toma o espaço num espírito de aventura e de invenção de outros lugares, outras partilhas, outras pulsações da imagem na tensão com o mundo. "O Câncer, filme meu, de $16 \mathrm{~mm}$, como todas as coisas que faço, estão ligadas a mim. O que acontece é que cada um tem sua forma. Em pintura, às vezes se decide fazer um mural, outras um quadro pequeno. Isso não quer dizer que o mural seja por isso mais importante" (Rocha, 2004: 179). Invenção também de outras variabilidades para a experiência, uma escolha pelo pequeno, pelo que pode resistir numa inquietude. Fazer filmes em devir-menor como maneira de tomar uma posição no mundo, não para colocar uma verdade absoluta quanto a formas válidas de fazer cinema, mas para situar-se no entre e tornar aberto o processo. Um modo de situar-se na dimensão de um movimento constituinte, mais do que no constituído. Tomar posição como um gesto de aproximação e distanciamento, em que reserva e desejo estão em jogo (Didi-Huberman, 2009). Tomar posição como algo distinto de tomar partido, na medida em que essa segunda abordagem é menos dialética e tensionadora de si mesma, aproxima-se muito mais da univocidade que da 
multiplicidade. Diria, então, numa aposta com Glauber, que vale pensar o cinema como campo aberto, em que não há um só caminho.

O Câncer era filme que não tinha sentido fazer em cor ou em $35 \mathrm{~mm}$. Não é filme comercial, não o fiz para ser exibido em circuito. É obra com que me diverti com meus amigos. Decidi fazer um filme em $16 \mathrm{~mm}$, chamei meus atores, meus amigos, e lhes disse: "Vamos fazer um filme". Fiz e não me custou nada, o material está aí, mas não está pronto e não sei quando vou prepará-lo. Fiz o filme também para demonstrar que em cinema não há um só caminho. [...] Naquela época alguns diziam: "O caminho do cinema é o filme a cor, de grande espetáculo", e outros: "O caminho do cinema é o filme de $16 \mathrm{~mm}$, underground". O caminho do cinema são todos os caminhos. Em vez de fazer uma superprodução em cores fiz um filme em $16 \mathrm{~mm}$, com equipamento reduzido, para demonstrar que alguém pode fazer tudo, que não existem preconceitos... Minha guerra é contra isto: a intolerância, os preconceitos, a demagogia. (Rocha, 2004: 180).

Sair, então, de oposições binárias. Os desafios estéticos e políticos do cinema são mais complexos do que uma perspectiva dicotômica poderia supor. Preferência, então, por esse uso do plural: caminhos - e diria também: resistências. Bifurcações, então. As invenções que cada filme possibilita dizem respeito às urgências movimentadas nas imagens pelos desejos. Trata-se de afirmar uma maneira de estar no mundo, que se afirma na produção de imagens e na necessidade de fazer cinema. Didi-Huberman (2012a), a todo o momento colocando o problema de um apesar de tudo, situa as fissuras que quatro fotografias arrancadas de Auschwitz fazem na história. Ele toma essas imagens para pensar resistências e sobrevivências que se dão em um campo de concentração, na tensão mesma com as câmeras de morte. Em meio à falta de esperanças: ainda assim, uma imagem. Em jogo de sombra e luz, de tensão com as formas, ela mesma é um gesto que diz da própria situação do fotógrafo, do momento de registro, do risco. 
Esta imagem, formalmente, não tem fôlego: pura 'enunciação', puro gesto, puro ato fotográfico sem fito (logo, sem orientação, sem alto nem baixo), ela permite-nos aceder à condição de urgência na qual quatro fragmentos foram arrancados ao inferno de Auschwitz. Ora, esta urgência também faz parte da história. (Didi-Huberman, 2012a: 58).

Essa figura conceitual de um apesar de tudo pode nos movimentar também com a urgência das imagens dos filmes de Glauber - é também o próprio Didi-Huberman que empreende essa operação teórica com uma série de outros trabalhos, em diferentes textos, guardadas sempre as singularidades de cada caso.

\section{Sonho e delírio}

Como extrair do caos a produção de outros espaços e tempos? Como enfrentar o caos? Uma experiência sensível caótica em Glauber tem relação direta com aquilo que ele propunha em Eztetyka do sonho, texto lançado em 1971. É um escrito instigador de uma nova postura sensível diante de um problema fundamental que inquieta o realizador, a articulação entre arte e revolução. As saídas que são apontadas a partir daí têm algo de bastante emblemático para uma tomada de posição, que se dá por uma abordagem da própria vida que não passe por uma lógica racional. É possível ler esse texto, acompanhando-o bem de perto, e daí discutir as implicações políticas do que Glauber chama de uma anti-razão. Convocar aqui os escritos de Glauber não implica uma tentativa de transpor o que se diz no âmbito textual para aquilo que se realiza no campo das formas fílmicas. Mas esse manifesto em especial do realizador é entendido aqui como emblemático de uma dobragem nas pesquisas de Glauber, um texto que também sofre desvios quando se passa à fabricação dos filmes, mas que parece ressoar, com variações concertantes, pelas obras que se seguem. A tensão que Glauber opera com o que chama de uma racionalidade burguesa pode ser 
vista mesmo como uma aposta teórica, não sistematizada como categorias, mas lançada como provocação a novas maneiras de traçar a linha entre o cinema e a política. Existe um desejo bastante forte de instigar uma arte revolucionária, preocupação que se situa em debates do período, mas também se carrega de uma abordagem singular em relação aos caminhos que se discutiam, já que não se trata mais nem de uma razão de esquerda nem de uma razão de direita. "Os sistemas culturais atuantes, de direita e de esquerda, estão presos a uma razão conservadora" (Rocha, 2004: 249). A operação que se abre leva o embate para o campo do pensamento, para instaurar um abalo nas matrizes que ordenam e encadeiam a percepção do mundo. Glauber quer produzir um cinema que desencadeie outras sensações, uma arte que não apele à formação de um todo intelectual mobilizador de ações, mas que possa encarar efetivamente um movimento caótico em direção à tensão com um mundo supostamente dado.

No embate feito com a racionalidade e a ordenação esquemática, cabe colocar mundos fora do lugar. Produção de caos e de desordem. Não se pretende explicar a pobreza, os processos de exclusão ou a situação social do Terceiro Mundo. E ao mesmo tempo há uma preocupação urgente de Glauber com tudo isso. Mas parece que as pesquisas dele ao longo dos anos, e as experiências de filmes como Deus e o Diabo na Terra do Sol, Terra em Transe e O Dragão da Maldade contra o Santo Guerreiro, carregaram para outra aproximação dos problemas que o inquietam.

A "Estética da fome" era a medida da minha compreensão racional da pobreza em 1965. Hoje recuso falar em qualquer estética. A plena vivência não pode se sujeitar a conceitos filosóficos. Arte revolucionária deve ser uma mágica capaz de enfeitiçar o homem a tal ponto que ele não mais suporte viver nesta realidade absurda. (Rocha, 2004: 251).

Existe aí uma decisiva indicação de outra aposta de agora em diante. As investidas são moduladas e já não têm a mesma orientação que vinha do 
outro manifesto fundamental do realizador, a Eztetyka da fome (1965). Era muito importante nesse primeiro texto o apelo a uma consciência e a definição de uma estética da violência, que fosse capaz de mobilizar para novas posturas a partir do choque. Não que Glauber abandone os procedimentos de que lançava mão ao longo da cinematografia dele, mas o que parece importante aqui é perceber como se processa uma passagem. $\mathrm{O}$ que se vê, tanto expresso nessa variação evidenciada nos dois textos quanto na matéria dos filmes, é uma inflexão: passar de uma compreensão racional a uma plena vivência é experimentar com a imagem a possibilidade de derivações, de errâncias, de enfeitiçamentos. São mesmo outras palavras que Glauber passa a convocar, a mágica, o místico, a possessão, o feitiço. Ele tenta agora outras conexões com o mundo, e aqui essas novas chaves podem ser entendidas em seu apelo direto ao corpo, a uma percepção que envolve com intensidade o sensível. É quase como se ele se aproximasse das preocupações de Benjamin (1994) com a perda da experiência e se remetesse a uma magia como dimensão possível para a revolução. "A revolução é uma mágica porque é o imprevisto dentro da razão dominadora" (Rocha, 2004: 250).

O homem já não suporta mais. E se ele chega a esse ponto, não é por uma via construída de modo dedutivo e sistemático. Também não é porque a ele se explicam dinâmicas de contradição social ou porque as estatísticas das Ciências Sociais informam e indicam interpretações sobre a pobreza, tomando aqui uma provocação feita por Glauber (2004: 248). Mas é por experimentar no corpo as forças que o apartam do mundo. "As vanguardas do pensamento não podem mais se dar ao sucesso inútil de responder à

\footnotetext{
${ }^{3}$ Não irei me deter aqui na discussão benjaminiana a respeito da experiência, mas cabe mencionar que, em textos como "Experiência e pobreza", Benjamin fala que as ações da experiência estão em baixa, sobretudo após o atravessamento da Primeira Guerra Mundial. Ao mesmo tempo, ele também detecta novas possibilidades que podem se abrir em meio à pobreza de experiência: os homens "aspiram a um mundo em que possam ostentar tão pura e tão claramente sua pobreza externa e interna, que algo de decente possa resultar disso" (Benjamin, 1994: 118).
} 
razão opressiva com a razão revolucionária. A revolução é a anti-razão que comunica as tensões e rebeliões do mais irracional de todos os fenômenos que é a pobreza. Nenhuma estatística pode informar a dimensão da pobreza" (Rocha, 2004: 250). Glauber faz aqui uma torção em paradigmas de leitura mais marcados pelo marxismo, ainda que sempre envolvido, ao seu modo bastante singular, nesse campo de pensamento. A revolução precisa ser entendida como anti-razão, essa é uma das questões centrais na estética do sonho. E nessa condição, ela não se articula a partir da oposição entre sistemas racionais, porque eles teriam como fundo uma mesma estrutura, incapaz de intervir no mundo. "Na medida em que a desrazão planeja as revoluções a razão planeja a repressão" (Rocha, 2004: 250). Uma racionalidade é, nesse sentido, repressora em sua base mesma, e não cabe invocar qualquer outro modelo como alternativa. A arte revolucionária defendida por Glauber, enquanto mobilizada pelo sonho, é uma arte de desconexões, descontinuidades, digressões, descentramentos. É um mergulho no caos, não para nele permanecer, mas para daí extrair movimento. A invenção se dá como liberação de formas esquadrinhadoras do pensamento e da produção de imagens.

A revolução, como possessão do homem que lança sua vida rumo a uma ideia, é o mais alto astral do misticismo. As revoluções fracassam quando esta possessão não é total, quando o homem rebelde não se libera completamente da razão repressiva, quando os signos da luta não se produzem a um nível de emoção estimulante e reveladora, quando, ainda acionado pela razão burguesa, método e ideologia se confundem a tal ponto que paralisam as transações da luta. (Rocha, 2004: 250).

As transações da luta precisam estar em movimento, que é parado quando existe uma ordem de dominação racional. No processo de combate em desrazão, há um coeficiente de destituição do instituído, ou da colonização, como é possível ler de forma recorrente nas discussões de 
Glauber e também ver nos filmes dele. O que essas palavras nomeiam, o burguês, o colonizador, o imperialismo - evidentemente, com as cargas próprias que têm, em termos de matrizes - é, sobretudo, uma instância de poder que submete tudo a um estado de fato, que faz da vida um conjunto de restrição de desejos e de possibilidades. E o que a desrazão vem contrariar é justo esse Poder transcendente, para colocar novas saídas, indicar linhas de fuga, caminhos ainda não explorados, sabores ainda não experimentados. A razão é policial, a desrazão é uma política. Uma estética do sonho existe como eterno movimento de investida no desequilíbrio, no heterogêneo e no alto índice de perturbação dos consensos. "O sonho é o único direito que não se pode proibir" (Rocha, 2004: 251). Essa é a saída que Glauber parece encontrar nesse momento das pesquisas dele, essa é uma fresta de possível que ele vislumbra, o lugar que ainda não foi capturado. Sonhar é elaborar novos mundos. No cinema de Glauber, não se trata de uma saída da luta, de fuga para não se pôr em combate, mas justo de linha de fuga desencadeada a partir da tensão com os fatos majoritários. É nesse ponto que se pode experimentar a invenção.

\section{Limiares}

Delirar, delirar: um delírio, dentro de uma perspectiva crítica à racionalidade burguesa, não é alienação do mundo, mas uma modalidade de se conectar com ele, operando desenraizamentos e fazendo fissuras. É uma maneira de apostar em outros paradigmas de pensamento, em outras cosmologias. Trata-se de distorcer um espaço, de confundir as palavras e se colocar em zonas de mistério. Delirar no limiar, desgarrar-se dos territórios e atingir estados de esgarçamento. A sequência de abertura de Claro já reúne todo um clima insólito e um conjunto de experimentações imagéticas e sonoras que escapam ao encaixe do entendimento e do inteligível. Seguimos Glauber e Juliet Berto em ações performáticas em meio às ruínas 
de Roma, com percursos desconexos e marcados por forte carga de alucinação. $\mathrm{O}$ filme instaura uma experiência de desequilíbrios no espaço turístico, na centralidade carregada de peso histórico. Delirar torna-se uma política de perturbação de centros e de estabilidades.

Logo no primeiro plano do filme, Juliet Berto está diante de um muro pintado com um rosto. Ela é vista de perfil, enquanto são ouvidos cantos. Repentinamente, uma mão vem por trás da atriz e, com um lenço vermelho colocado na boca dela, a puxa para fora do quadro. Um corte introduz uma tela branca por alguns segundos, à qual se segue um plano completamente aberto que mostra a imensidão das ruínas de Roma e a pequena figura de Berto, ajoelhada, inicialmente bem distante. A mulher dá início a movimentos performáticos pelo espaço, sem finalidade, numa temporalidade aberta, numa disponibilidade em fazer travessias. Os cantos permanecem, vozes que gritam, sonoridades que remetem a um tom ritualístico. É Glauber falando uma língua indígena, fora de quadro. Aos poucos, o plano se fecha mais e se aproxima da atriz que abre os braços, caminha, leva as mãos à cabeça. Ela começa a responder a Glauber, retornando com as mesmas palavras, entrando na mesma língua. Há aqui uma interação direta entre quem está no campo e quem está no antecampo, tanto com a mediação mais direta das palavras, quanto a partir de gestos e olhares de Berto. Ela prossegue o percurso, fazendo um trajeto da esquerda para a direita e depois se dirigindo ao fundo, partindo em maior velocidade, até começar uma corrida, rumo a se perder de vista. Alguns turistas, muitos deles com câmeras fotográficas, olham sorrindo para o acontecimento desencadeado, alguns chegam mesmo a acenar. Após a corrida de Berto, a câmera se desvia um instante dela, se desloca para a esquerda, filma mais do espaço e do céu, até retomar para a direita e tentar localizar mais uma vez a atriz, que agora volta do fundo, gritando novamente para o antecampo. Passa-se a uma movimentação cada vez mais dispersa, de ir e vir, de se perder constantemente pelo espaço e de mapear a paisagem. 
Esse procedimento lançado logo de entrada no filme é prolongado nas cenas seguintes, que vão acompanhar ainda o percurso de Berto. Também se trata do percurso da própria obra em errância. Em um momento, ela rola pelo chão, diante do Coliseu, enquanto Glauber salta por cima do corpo dela em movimento. Mais uma vez, os passantes olham, ora com uma curiosidade e um sorriso, ora com certo assombro. O corpo esgotado de Berto precisa ser erguido por Glauber, mas ela logo se levanta e começa a mostrar os dedos em tom provocativo, segue o caminhar, distanciando-se da câmera, enquanto uma mulher que estava sentada olha com espanto para a câmera, se ergue e passa apressada, cruzando o campo visual. Intervenções no som fazem os áudios de diferentes sequências se interpenetrarem, misturando o som direto com o prolongamento de vozes ouvidas momentos antes ou ainda com uma música que começa a tocar. Berto passa também a enunciar algumas frases em francês: "Ouço a voz de fantasmas", diz repetidas vezes. "Eu mato, eu mato, eu mato". Ela estala os dedos e aponta para a câmera com um gesto que imita a posse de uma arma. "Vemos nosso reflexo, através da realidade, através dos sonhos", diz em dois planos distintos, cortados e unidos para completar a frase que sai fragmentada. "A destruição da civilização ocidental”, segue ela, estendendo os braços. Em meio a esses planos dos gestos e das ocupações de Berto em Roma, surgem imagens que mostram separadamente algumas estátuas nas ruas, monumentos de uma civilização, de períodos clássicos, de um império construído há muitos anos. A câmera delirante, o percurso imagético que vira balbucio, reinvenção de linguagem, encontra a história, toda a carga de uma civilização construída ao longo dos tempos, em meio a inúmeros processos de estabelecimentos de partes, em distribuições litigiosas do sensível, para retomar termos de Rancière (1996).

Nesse embate com Roma, a poética de Glauber vira o movimento do estrangeiro que busca produzir uma outra espessura de tempo, que desarticula o monumento erigido para contar a História de grandes 
empreendimentos e se empenha em abrir frestas, pequenas formas delirantes de devir. Essa tensão, que começa a se constituir primeiramente como imagem, passa também a se evidenciar no discurso em off que o realizador enuncia, na medida em que surgem estátuas, praças e mais extensões da grandiosidade de um império. Glauber fala de Otávio Augusto, o imperador romano que empreendeu expansões de poderes, estabeleceu dominações e uma soberania romana sobre outros povos. "A conquista imperialista de Roma sobre o Terceiro Mundo", define Glauber. Com um plano aberto, ele filma de cima a estátua de Otávio Augusto montado em um cavalo, no centro de uma praça, tendo em volta outras estátuas e uma amplitude de espaço. "A sede do imperialismo, fixada aqui embaixo das patas desse cavalo monstruoso. Essa imagem é a última imagem do Ocidente, la ultima immagine del Occidente”. A fala de Glauber começa a misturar as línguas, uma penetrando a outra. Ele chega a conversar com Berto em outro instante, falando um italiano mergulhado pelo português, ouvindo as respostas da companheira em francês e replicando também com variações de francês e italiano. Passa-se, então, a torções com uma forma estável de filmar e de falar.

Propondo o conceito de imagem-exílio nesse filme de Glauber, Hudson Moura (2005) já desenvolveu uma análise detida no aspecto das línguas que proliferam em Claro, a partir de uma ênfase na situação de exilado do realizador em Roma. Glauber opera conexões com todo um mundo de referências. Da discussão de Moura, é interessante reter as implicações entre dois movimentos gerais do filme, a superposição de línguas e a de imagens. Existe um aspecto cultural nesse entrecruzamento de idiomas, mas parece aqui importante também pensar como isso reverbera de modo bastante emblemático na experiência estética do filme. Não estamos, simplesmente, diante da constatação de uma diversidade cultural, de um cinema mundial ou globalizado, tão recorrente em casos recentes de produção industrial. $\mathrm{O}$ exílio aqui é efetivamente imagético, 
desestabilização de nacionalidades, justo enquanto operação na plasticidade e na sonoridade. Moura (2005) destaca as metamorfoses dos espaços, as misturas dos procedimentos de ficção e documentário, os cortes na palavra. Ainda segundo o autor, não se trata de construir uma história sobre o exílio, mas de colocar o exílio em potência, tornar sua força pulsante e em transe, na ordem de um insuportável (2005: 98-100). A política é formulada mais como uma força do que como um discurso (2005: 102). Essa força torna-se sensível nas transgressões operadas por Glauber no âmbito das formas cinematográficas, na abertura que faz em uma sequência como a discutida aqui, com Berto rolando pelo chão diante do Coliseu, ou na ida a um bairro periférico de Roma, onde empreende sobreposições de imagens e um encontro com corpos singulares. Retomando Moura (2005), trata-se de levar para as imagens a hesitação expressa na fala, a partir do contágio entre as línguas.

O procedimento que consiste em cortar a palavra e torná-la hesitante se traduz em imagens. Há, ao longo de todo o filme, sequências interrompidas, inacabadas, cenas sem som, sons ouvidos a partir de uma cena precedente e que retornam, barulhos que tornam inaudíveis as palavras e as reenviam ao segundo plano, superposições de imagens e de cortes das cenas. (Moura, 2005: 96). ${ }^{4}$

Fazer a imagem delirar. Ela atinge níveis de suspensão, ela traça desvios. Berto guia o filme para a perda de uma conexão segura com o mundo, para estados de embriaguez. Um movimento delirante é de um lado o do corpo que se libertou para rolar ou para ir e vir, sem ordenações prévias, sem uma funcionalidade. E de outro, é o da câmera, completamente mergulhada no processo e tornada uma viajante em exílio. O filme não é

\footnotetext{
${ }^{4}$ Tradução minha do original em francês: « Le procédé qui consiste à couper la parole et à la rendre hésitante se traduit en images. Il y a, tout au long du film, des séquences interrompues, inachevées, des scènes sans son, des sons entendus lors d'une scène précédente et qui reviennent, des bruits qui rendent inaudibles des paroles en les renvoyant au second plan, des superpositions d'images et des coupures de scènes ».
} 
uma narrativa pessoal que se conta sobre a experiência de estar fora do próprio país, ele já surge em meio a esse lugar de correlação de mundos. Não se torna uma expressão da subjetividade do realizador em uma suposta nostalgia da pátria. Aqui há muito mais uma tomada de posição diante do capitalismo mundial e da História contada a partir de uma perspectiva vertical em detrimento das potências dos povos submetidos às dominações dos colonizadores. E as relações instauradas nas imagens de Claro estão estreitamente conectadas às dobragens já empreendidas por Glauber em outros dois filmes também de exílio, Cabeças cortadas (Cabezas Cortadas, 1970), filmado na Espanha, e O leão de sete cabeças (Der leone have sept cabeças, 1970), rodado no Congo africano. São também obras fundamentais de enfrentamento e de passagem para uma estética do sonho, já marcadas por uma postura de delírio. A posição de exílio em Glauber faz com que ele se empenhe num trabalho de pesquisa em que as singularidades de cada lugar são pensadas em conexão com as lutas e os processos de subordinação na conjuntura do capitalismo. E isso se dá como trabalho de imagens, como operação de escritura fílmica.

Didi-Huberman (2009), ao tratar de algumas pesquisas de Brecht, o Diário de Trabalho e o $A B C$ da Guerra, enfatiza o quanto a posição de exílio do artista no período em que se dedicava a essas obras é tornada um trabalho de escritura e de pensamento apesar de tudo (Didi-Huberman, 2009: 13). A condição da escrita desterritorializada, sempre à beira de uma próxima partida, numa insegurança constante quanto ao porvir, suscitava uma poesia não só na guerra, quanto uma poesia de guerra, diz ainda DidiHuberman (2009: 13). "Poesia abundante, de outros lugares, exploratória e prismática: longe de se redobrar sobre a elegia, longe de sacrificar a qualquer nostalgia que seja, o escritor multiplica aqui as escolhas formais e os pontos de vista" (Didi-Huberman, 2009: 14). Evidentemente, as situações de exílio de Glauber e de Brecht não são as mesmas, nem o são as matérias artísticas que tomam para si. Mas vale reter aqui essa discussão que Didi- 
Huberman leva adiante, na medida em que ele detecta no exílio a possibilidade de um trabalho, que se modula na forma, reinventa gestos, desmonta e remonta. É criada uma dimensão de desordem para tomar posição, para engajar-se no mundo, em apostas quanto a novas condições de criação e de vida.

Delirando, Glauber experimenta uma dimensão de mistério na linguagem, uma maneira de fazer o cinema estranhar o próprio cinema. No caminhar sem referência segura, a imagem pode ser produzida de forma cambaleante, o corpo pode vacilar na cena, a fala pode se desorganizar em palavras que se tornam puras vibrações. O delírio se investe de uma postura de resistência à expropriação da linguagem pelo capitalismo, à destinação de lugares, ao constrangimento de outros mundos possíveis. Em um momento, Juliet Berto fala a respeito de um esgotamento das palavras. Ela está sozinha no plano, com um chapéu, o quadro recortando seu rosto ao lado da estátua de um leão.

Não há mais palavras a dizer, pois a linguagem não é mais a linguagem, e a diferença entre o ato e a palavra caiu em algo de unilateral, onde toda a cor, onde todos os sons, onde todas as formas se agruparam num caos "cosmono-demonical", onde eu esqueço o que chamávamos de lucidez, pois gera, gera, como algo cristalino e novo, como novos sons, onde os perfumes, que poderiam começar... Não, não é ele.

A própria fala é dita em estado de alteração, ela vai se desfazendo aos poucos, chegando a um liame. O filme parece explicitar uma questão cara ao próprio movimento que tenta instaurar. A linguagem não é mais a linguagem. As palavras tornam-se inoperantes, já não cabe proferi-las. $\mathrm{O}$ que se constata é um abismo, ato e palavra em defasagem. E o que isso implica para a cena fílmica? Como a obra se situa nesse lugar em que todas as formas se agrupam num caos "cosmono-demonical"? Há nas sequências ficcionais de Claro um impulso maior para a marcação de emblemas, para o recurso a personagens que proferem discursos mais circunscritos ao campo 
das insatisfações de Glauber com situações sociais do mundo. Mas é preciso ainda se colocar de forma mais detida diante dessa ficção singular que é operada no filme, a penetrar o real, que também insiste e pulsa por todo o corpo da obra. Porque é também uma ficção delirante, que mesmo expressando, em alguma medida, uma discursividade pontuada por teses, cria um movimento de tal modo imprevisto que já não se podem controlar os modos de as imagens resvalarem no campo da experiência e virarem linhas que escapam ao próprio curso do filme.

Há um plano aberto e vários personagens circulando livremente pela cena, no espaço de um jardim, em torno de uma mesa que contém pedaços de carne. É uma sequência profundamente marcada por movimentos performáticos e também gestos teatrais. Mais uma vez, é Berto quem conduz a encenação, enunciando o discurso. À sua volta, todos parecem completamente independentes de qualquer fala, desligados, de um modo mais evidente, daquilo que é dito. Dois homens circulam em torno da mesa, conversando com gestos largos. Outros dois e uma mulher rodopiam livremente, dançam, também fazem o movimento circulatório em torno do centro da cena, mas segunda uma linha desmesurada e desregrada. O plano se fecha progressivamente: mais cerrado, ele faz com que os personagens estejam por mais tempo fora de quadro, criando na imagem um acúmulo de gestos, de pedaços de movimentos, que muitas vezes apenas reverberam indiretamente no campo do visível, não chegando a ocupar efetivamente o quadro. Aos poucos, a câmera se movimenta para baixo e mostra em mais detalhes o que está sobre a mesa do centro, algo como a carne crua de animais, como se estivéssemos também num ritual de sacrifício e de oferenda. Um corte leva a um novo plano longo, também de movimentação intensa e de desconexão entre os corpos. Agora os personagens que apenas circulavam também falam, mas as palavras não são encadeadas, elas são, sobretudo, soltas, e raramente formam frases completas. A mulher aparece com os seios expostos, dos quais um homem se aproxima com a boca. Os 
pedaços de carne são erguidos. Quando Berto surge novamente, ela coordena a encenação, oferece um punhal a um dos homens para que mate o outro. O fim da sequência coincide com a morte desse personagem, um plano fechado sobre seu rosto.

E o que fala Berto nesses momentos? Ela se remete aos próprios personagens em cena, que já estiveram em sequências anteriores, mas agora são quase que apresentados por essa mediadora da cena. Ela fala ainda de algo já lançado por imagens anteriores, a decadência da civilização ocidental, o desmoronamento de Roma, a exploração do homem pelo homem. "O povo nascerá dessa cidade onde tudo o que existe é disposto em cartões-postais. Uma cidade de cartões-postais, que rodopia e se movimenta em meio a turistas loucos por um passado doente. Doente por um capitalismo que está explodindo, degenerando, totalmente perdido". Ela cita Ho-Chi-Mihn e repete a ideia do vermelho, de um sangue vermelho. De algum modo, esse discurso se situa em zona bastante estratégica no conjunto do filme, após uma série de sequências que são, de certa maneira, explicadas aqui, e antes de outras que também repercutem esse anseio de que um povo nasça dessa cidade - se pensarmos, principalmente, na ida à borgata, em uma outra sequência fundamental de Claro.

Mas o didático e o explicativo são também borrados. Se é possível identificar um esquema geral que torna cada personagem um emblema em determinado jogo de sentido: o capitalista, o colonizador, os burgueses, a prostituta (como também era a marca em $O$ Leão de Sete Cabeças, por exemplo), há uma dramaturgia que vem se elaborar como outra política do espaço da cena. Essa outra inscrição cênica coexiste, em tensão, com a lógica explicadora, e torna potente na ficção a mesma carga de deambulação delirante que marcava os percursos de Berto pelas ruas de Roma, quando o filme abria-se, de forma mais explícita, a um regime documental. As palavras entoadas enquanto os personagens circulam entram naquele abismo que era justamente identificado por Berto entre ato e palavra, e daí a crise 
que o filme põe em movimento é uma irremediável cisão experimentada no jogo ficcional em que a metáfora tenta se desenhar. Enquanto o regime da significância tenta surgir, uma força de presença sempre a coloca para dançar. Se existe uma ordem burguesa a ser desmontada, uma história única de Roma a ser tensionada, a força maior do filme para levar esses processos adiante está nesses corpos que jogam sem finalidade pelo espaço, tanto nos momentos da ficção quanto do documentário. É quando uma possibilidade de vida se abre no acontecimento da cena, quando a dramaturgia traz para a sensação o enfrentamento que tenta expor no âmbito do discurso, a respeito da necessidade de superar o capitalismo. $\mathrm{O}$ corpo precisa não suportar mais esse regime sensível. A vida precisa se fazer na cena como irrupção de outros desejos, que surgem de uma delirante rarefação do dizível, do visível e do audível, para resistir aos processos de captura e de ofuscamento por parte dos poderes.

Benjamin (1994) fala de um espaço da imagem que surge na política, o que pode ser aqui uma figura bastante potente para situar melhor essa tensão exposta nesse cinema de Glauber. "É na política que a metáfora e a imagem se diferenciam da forma mais rigorosa e mais irreconciliável. Organizar o pessimismo significa simplesmente extrair a metáfora moral da esfera da política, e descobrir no espaço da ação política o espaço completo da imagem" (Benjamin, 1994: 34). É, então, nesse processo, que as imagens não param de se fazer. E não param porque existe uma política de insistência que não organiza a metáfora nem a moral, mas um espaço completo de imagem. Organizar o pessimismo é a possibilidade de aposta numa política da imagem. E Benjamin ainda completará mais adiante essas transformações para o que chama de um espaço da imagem, indicando que ele se modifica em "algo de mais concreto ainda: espaço do corpo" (Benjamin, 1994: 35). Espaço do corpo e espaço completo da imagem são experimentações de tensões revolucionárias, que se dão materialmente. Elas precisam de um espaço efetivamente - e de um tempo também, poderia ser 
acrescentado. O que Benjamin recusa é o caráter contemplativo da experiência. Poderia dizer que é também uma tensão com a abordagem no âmbito do puro intelecto, de onde vem essa demanda do corpo, e de um corpo que possa se desdobrar em corpo coletivo para gerar contágio por meio de uma physis. Delirar pode ser uma maneira material de fabricar outros espaços de imagem e de corpo.

Nessa linha, os esforços do surrealismo, se seguirmos com a leitura de Benjamin (1994), já estabeleciam como questão central uma política poética implicada numa maneira de delirar relacionada à embriaguez. "Mobilizar para a revolução as energias da embriaguez" (1994: 32). Benjamin fala de uma iluminação profana, ligada tanto ao uso de drogas, o haxixe, o ópio, quanto à própria experiência desencadeada pela arte, pelo pensamento, pela deambulação na cidade. Era nesse âmbito que ele se esforçava em situar os trabalhos dos surrealistas. "O homem que lê, que pensa, que espera, que se dedica à flânerie, pertence, do mesmo modo que o fumador de ópio, o sonhador e o ébrio, à galeria dos iluminados. E são iluminados mais profanos”. (Benjamin, 1994: 33). Novamente, aqui existe uma relação com forças cósmicas, que impliquem o homem num movimento revolucionário, ligado ao caos e a uma desordem produtiva de novos mundos. Em Rua de mão única, ele chega a apontar também para essas potências da embriaguez. "É embriaguez, decerto, a experiência na qual nos asseguramos unicamente do mais próximo e do mais distante, e nunca de um sem o outro. Isso quer dizer, porém, que somente na comunidade o homem pode comunicar em embriaguez com o cosmos" (Benjamin, 1987: 64). Benjamin acrescenta aí outro elemento para pensar a integração que se pode alcançar com o cosmos. É que além da embriaguez, ele fala também de uma comunidade. A experiência cósmica é da ordem de um comum, e podemos traçar conexões variadas com o mundo, na alteração e no trânsito possibilitados pela embriaguez. Talvez, assim, o povo nascerá de uma Roma doente, como invocado por Berto, não tanto por uma 
chamada intelectual, mas por certa medida de delírio, por um trânsito que promove comunicações com o cosmos. Uma outra chave aqui para pensar o problema do comum pode ser arriscada: a comunidade agora fundada pela experiência do desnorteio e da implicação do corpo no universo. Não uma contemplação do cosmos, mas uma integração cósmica que instala um interstício para o em-comum. Não uma racionalidade dedutiva, mas uma liberação de sonhos. "Eu acredito que a obra de arte é um produto da loucura, no sentido em que fala o Fernando Pessoa, que fala o Erasmo, quer dizer, a loucura como a lucidez, a libertação do inconsciente" (Rocha, 2006: 333). Glauber estava preocupado com a dimensão produtiva desse inconsciente, liberado para gerar, maquinar, desencadear espaços de imagem, espaços de corpo. ${ }^{5}$

O delírio pode ser pensado como um processo que arrasta as palavras de um extremo a outro do universo, como diria Deleuze (2011: 9). Esses movimentos de arrastar são bastante concretos aqui, uma maneira de pensar as palavras, enunciadas num filme ou escritas num livro - Deleuze trata especialmente da literatura, nessa discussão trazida aqui. Mas é também uma possibilidade de operar com as imagens, também carregadas entre extremos, deslocadas de forma intensa. Trata-se de traçar desvios na língua, operar devires variados. Delirar é minorar uma língua maior. "Dirse-ia que a língua é tomada por um delírio que a faz precisamente sair de seus próprios sulcos" (Deleuze, 2011: 16). É preciso pôr em evidência no delírio a criação de uma saúde, uma possibilidade de vida, de invenção de um povo, indica Deleuze.

A literatura é delírio, mas o delírio não diz respeito a paimãe: não há delírio que não passe pelos povos, pelas raças e tribos, e que não ocupe a história universal. Todo delírio é histórico-mundial, "deslocamento de raças e de continentes".

\footnotetext{
${ }^{5} \mathrm{Na}$ fortuna crítica a respeito de Glauber Rocha, existe um estudo bastante central que se situa no campo das relações entre cinema e psicanálise, desenvolvido por Raquel Gerber. Ver: GERBER, Raquel. O mito da civilização atlântica. Glauber Rocha, Cinema, Política e a Estética do Inconsciente. Petrópolis: Editora Vozes, 1982.
} 
A literatura é delírio e, a esse título, seu destino se decide entre dois polos do delírio. O delírio é uma doença, a doença por excelência a cada vez que erige uma raça pretensamente pura e dominante. Mas ele é a medida da saúde quando invoca essa raça bastarda oprimida que não para de agitar-se sob as dominações, de resistir a tudo o que esmaga e aprisiona e de, como processo, abrir um sulco para si na literatura. (Deleuze, 2011: 15).

O capitalismo doente, desmontado nas imagens delirantes de Claro, precisa ser posto em crise por essa outra espécie de delírio, medida de saúde, que pode fazer sulcos na linguagem, num cinema estruturado, para desencadear devires variados que apontam para a vida, para o desejo de viver de modos inéditos, libertos das dominâncias e do passado doente. Como já observou André Brasil (2008), ao discutir o delírio e o transe em Aboio (Marília Rocha, 2005) e Andarilho (Cao Guimarães, 2006), as imagens deliram na contramão do delírio do capitalismo, que se esforça em dissociar experiência e linguagem. "Cao Guimarães nos mostra a linguagem em sua forma pura, que é, paradoxalmente, sua extrema impureza: a substância heterogênea dos sons, do balbucio, do grito, do gesto, da performance, do esforço, a substância do silêncio", diz Brasil a respeito de Andarilho. Em Aboio, como tentei pontuar também em Claro, existe uma tensão entre a explicação e o transe. E a força do filme, seguindo com Brasil, está menos nos momentos didáticos que na impotência, "naquilo que ele não consegue explicar nem controlar" (Brasil, 2008). A linguagem dos vaqueiros se transforma em música e parte diretamente da experiência cotidiana. Trata-se, nos dois filmes, de "um delírio que é a própria realidade, o delírio da experiência, seu lastro" (Brasil, 2008). Existem novas possibilidades de a linguagem se conectar com a experiência e de o delírio efetivamente ter conexão com uma vida, com a movimentação do viver. Nos filmes de Cao Guimarães e de Marília Rocha, a imagem pode guardar seu mistério e escapar aos clichês e aos estereótipos. "A linguagem, neste caso, 
está colada ao corpo, aos gestos, à paisagem, à experiência sensível. Longe da abstração das gramáticas e dos manuais técnicos, ela delira, canta, entra em transe, fundindo, em um só corpo, os gestos, as palavras, a natureza, os mitos" (Brasil, 2008).

Se em Claro, as imagens têm essa potência de delirar, elas partem para caminhos desconhecidos, misteriosos. Caminhos de um cinema que ainda não está dado, que se inventa como feitiçaria dos sentidos, como transe e passagem. Berto não enuncia apenas discursos, ela rola no chão, canta e detecta, de forma bastante emblemática, os impasses da palavra. Fazer a linguagem delirar não é um objetivo, mas um caminho de tensões abertas, em que as incertezas proliferam. $\mathrm{O}$ delírio como processo que fende o cinema, faz nele sulcos. Delirar nos limiares da imagem e instaurar aí um espaço de corpo. Talvez sejam essas algumas modulações, nesse regime de urgência e de delírio, que esses filmes de Glauber nos colocam para pensar o cinema e a política da imagem. Ao optar pelo enfoque, sobretudo, em Claro e Di Cavalcanti, a tentativa aqui é perceber uma curva, algo como uma inflexão na cinematografia glauberiana, que não deixa de estar absolutamente conectada com o mundo e com o real, mas se investe de outros paradigmas para o pensamento, especialmente mais enfeitiçados e mágicos, como o próprio realizador apontava na sua estética do sonho. Se assim podem ser fabricados filmes documentários em profícua tensão com o real, é porque as formas da imagem não cessam de se contaminar pela experiência do encontro entre corpo e mundo. A linguagem delira justo porque o real nelas insiste e pulsa.

\section{Referências bibliográficas}

ARAÚJO SILVA, Mateus (2012), "Glauber Rocha e os Straub: diálogo de exilados" in E. Gougain, F. Taddei, P. Mourão e M. Araújo Silva 
(Orgs.), Straub-Huillet, São Paulo: Centro Cultural Banco do Brasil, 2012, pp. 243-263.

BENJAMIN, Walter (1994), Obras Escolhidas I. Magia e técnica, arte e política: ensaios sobre literatura e história da cultura, $7^{\mathrm{a}}$ Ed., São Paulo: Brasiliense.

(1987), Obras Escolhidas II. Rua de mão única, São Paulo: Brasiliense.

BRASIL, André (2008), "Quando as palavras cantam, as imagens deliram" in Revista Cinética. Disponível em: http://www.revistacinetica.com.br/aboioandarilho.htm

COMOLLI, Jean-Louis (2008), Ver e poder - a inocência perdida: cinema, televisão, ficção, documentário, Editora UFMG.

DELEUZE, Gilles (2011), Crítica e Clínica, 2a Ed, São Paulo: Ed. 34.

DIDI-HUBERMAN, Georges (2012a), Imagens apesar de tudo, Lisboa: KKYM.

(2008), "La emoción no dice “yo". Diez fragmentos sobre la libertad estética" in JAAR, Alfredo, La política de las Imágenes, Santiago de Chile: ediciones metales pesados.

(2012b), "Quando as imagens tocam o real” in Pós: Belo Horizonte, v. 2 , n. 4 , pp. $204-219$.

(2009), Quand les images prennent position. L'oeil de l'histoire, 1, Paris: Les Éditions de Minuit.

MOURA, Hudson (2005), Glauber Rocha et L'image-exil dans Claro, Cinémas (Montréal), Montréal, v. 15, p. 81-103.

RANCIÈRE, Jacques (1996), O desentendimento, São Paulo: Ed.34.

ROCHA, Glauber (2004), Revolução do cinema novo, São Paulo: Cosac Naify. 
Glauber sob um regime de urgência

\section{Filmografia}

Aboio (2005), de Marília Rocha.

Andarilho (2006), de Cao Guimarães.

Cabeças cortadas (1970), de Glauber Rocha.

Câncer (1968-1972), de Glauber Rocha.

Claro (1975), de Glauber Rocha.

Deus e o Diabo na Terra do Sol (1964), de Glauber Rocha.

Di Cavalcanti (1977), de Glauber Rocha.

Letícia e Mossa no Marrocos (1971), de Glauber Rocha.

O Dragão da Maldade contra o Santo Guerreiro (1969), de Glauber Rocha.

O leão de sete cabeças (1970), de Glauber Rocha.

Paloma, Paloma (1972), de Glauber Rocha.

Terra em Transe (1967), de Glauber Rocha. 